\title{
How Faith Development Interviews Reflect Biographical Paths to Xenosophia: Conceptual and Methodological Considerations
}

\author{
Heinz Streib and Barbara Keller
}

Chapter 3 in: H. Streib, C. Klein (eds.), Xenosophia and Religion.

Biographical and Statistical Paths for a Culture of Welcome,

https://doi.org/10.1007/978-3-319-74564-0_3

\section{Conceptual Considerations}

\section{Fowler's Model of Faith Development}

The notion that religiosity may change over the course of a person's lifetime is not completely new. But an understanding of the changes of religiosity in terms of structural-developmental progress, as it became popular in the 1970s and 1980s, has established a new line of research that accepts inspirations from Piaget, more precisely: from Kohlberg's (1984) interpretation of Piaget's developmental perspective into theory and research on religion. This appreciation of Piagetian structuralism is certainly true for Fowler's (1981) influential model, but Fowler was rooted deeply enough in religious studies and theology to arrive at a rather multi-dimensional construct of religion - or in his terms: of 'faith.'

The decision to use the term 'faith' was greatly inspired by Cantwell Smith (1963, 1979). But Fowler's 'faith' also reflects perspectives of H. R. Niebuhr (1943) and Tillich (1957). Fowler (1981, p. 92) defined 'faith' in the following way:

In the most formal and comprehensive terms I can state it, faith is: People's evolved and evolving ways of experiencing self, others and world (as they construct them) as related to and affected by the ultimate conditions of existence (as they construct them) and shaping their lives' purpose and meanings, trusts and loyalties, in the light of the character of being, value and power determining the ultimate conditions of existence (as grasped in their operative images - conscious and unconscious - of them). 
[86] This definition characterizes faith as meaning-making (as in the subtitle of Stages of Faith) and thereby reflects functional and structural perspectives. Furthermore, by the use of "ultimate conditions of existence," traditional material definitional characteristics of religion are avoided. Instead, the concept of faith, according to Fowler (1996, p. 168-167), "aims to include descriptions of religious faith as well as the less explicit faith orientations of individuals and groups who can be described as secular or eclectic in their belief and values orientations." We note that 'faith' is not confined to vertical transcendence, but meant to include non-theistic and implicit versions of religion (cf. Streib \& Hood, 2011, 2016b).

Fowler conceptualized 'faith' broadly and has assumed that a variety of structural aspects are characteristic for faith on a certain stage. Thereby, he included not only structural aspects such as cognitive development (adopted from Piaget), perspective-taking (adopted from Selman) and moral development (adopted from Kohlberg), but he has added four more aspects: bound of social awareness, locus of authority, form of world coherence, and symbolic functioning. These seven aspects are assumed to form a coherent heptagonal combine. Thus, stages are defined as "structural wholes," i.e. the same cognitive structures are present across all seven aspects.

The stages of faith are assumed to progress in an invariant, sequential, irreversible, hierarchical and universally valid sequence - largely following Kohlberg's criteria of "hard" stage development (Kohlberg, Levine, \& Hewer, 1983). Fowler assumed the faith stages to progress (loosely related to age) in the following sequence: Stage One of intuitive-projective faith ( $<6$ years), where the child, dependent on caretakers, has yet to learn to distinguish between himself and objects and fantasy and reality; Stage Two of mythic-literal faith (7-12 years) that is oriented to reward and punishment; Stage Three of synthetic-conventional faith (adolescence, adulthood) that is oriented to one's own group and implicit reasoning; Stage Four of individuative-reflective faith with explicit systemic reasoning (late adolescence; adulthood); Stage Five of conjunctive faith that is characterized by 'second naiveté' recognizing the evocative power inherent in symbols, including symbols of other religious traditions (adulthood); and, finally, and rarely identified in empirical reality, Stage Six of universalizing faith, described as loyalty to being and purged of egoistic strivings (adulthood and late adulthood). The sequence of faith stages is visualized as a spiral by Fowler (1981, p. 275).

Taking the sequence of faith stages and the seven aspects together, Fowler (1980) imagined 'faith' as a heptagon, as visualized in Fig. 3.1.

This heptagon, introduced by Fowler in 1980, can be taken as the most influential visualization of his model because it structured not only theory, but also research in faith development (even though the figure was not included in Stages of Faith). The Manual for Faith Development Research is structured like a grid of this heptagon. In a nutshell, this heptagon grid is visible in a large table in Stages of Faith (Fowler, 1981, p. 244-245). The Manual thus presents, for each stage-aspect combination (i.e. each cell in the heptagon grid), coding criteria for rating the selection of FDI 
Fig. 3.1 Aspects and stages in faith development (The Heptagon Model, Fowler 1980, p. 32) Note A = Form of logic; $\mathrm{B}=$ Perspective-taking; $\mathrm{C}=$ Moral judgment; $\mathrm{C}=$ Bound of social awareness; $\mathrm{E}=$ Locus of authority; $\mathrm{F}=$ Form of world coherence;

$\mathrm{F}=$ Symbolic function; numbers 1 to 5 indicate the faith stages

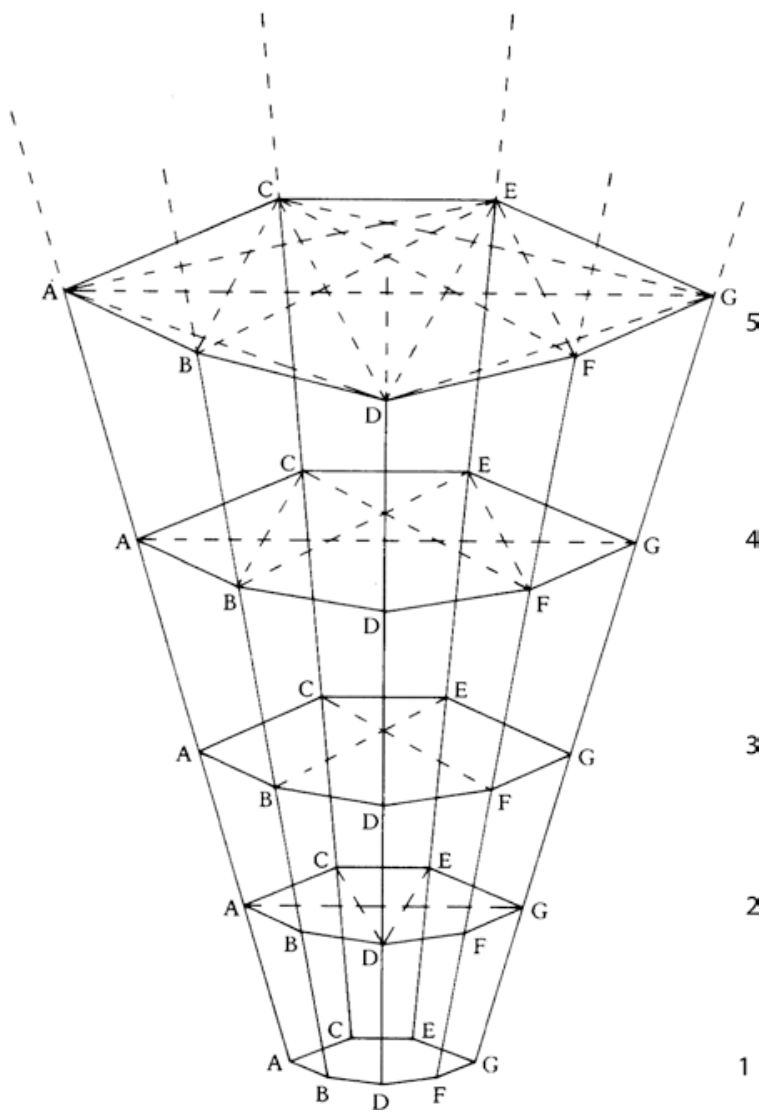

[87] questions that are considered relevant for this cell. Because we regard it as very helpful for evaluation, we have kept this structure also in the 3rd edition of the Manual (Fowler, Streib, \& Keller, 2004) and further revisions.

\section{The Religious Styles Perspective}

The religious styles perspective (Streib, 2001, 2003a, 2003b, 2003c, 2005b, 2013), which has been elaborated as a result of critical-constructive engagement with Fowler's project (Streib, 1991), has become the conceptual framework on which our research with the FDI in the completed and current projects is based. The religious styles perspective intends to open up attention to the flexibility and permeability of religious development, rather than confining development to the sequential abandonment of stages that are considered structural wholes. The term 'style' is used to 


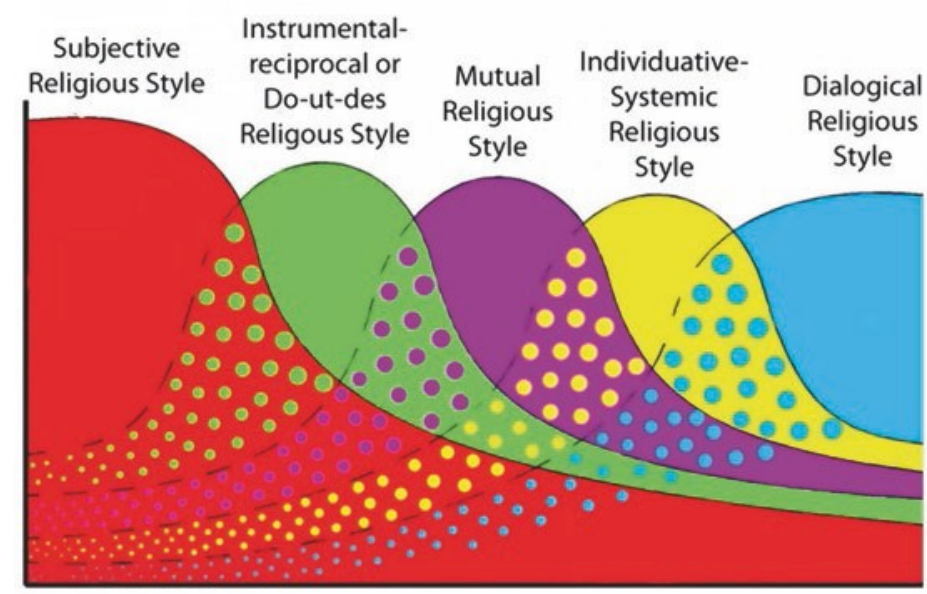

Fig. 3.2 The religious styles (Streib, 2001)

[88] avoid prejudgment for, and fixation on, a linear, irreversible developmental model and to open the perspective on the multi-directionality and diversity of developmen- tal trajectories of our respondents. ${ }^{1}$ While the conceptual discussion is not the focus of this chapter, it is important to refer to the religious styles perspective here, because of its consequences for the evaluation method. And this has been carefully but extensively revised in light of the religious styles perspective, as will be detailed below.

The conceptual base for the revisions can be explained also with reference to Fig. 3.1. Insofar the heptagon depicts a model of faith development, understood as sequential abandonment of absolutely flat planes (structural wholes), this model needs to be rejected with reference to empirical data that evidence differences in stage assignments of one stage or even more than one stage as rule, rather than as exception. Nevertheless, as a heuristic tool for structuring the evaluation of the FDIs and identifying the religious styles, the heptagon grid has proven useful.

For a visualization of the religious styles perspective, we present in Fig. 3.2 the model, which was inspired by Loevinger's (1976) mile stone model and has been included in an earlier version in the 2001 article (Streib, 2001). The figure intends to account for precursors and post-peak sediments. This may help to understand that more than one style is available at one time in a person's life. The sediments also indicate that past styles are available for revivals as, for example, in mid-life fundamentalist conversions (Streib, 2001, 2007).

\footnotetext{
${ }^{1}$ A note on terminology: We use in this chapter and many other chapters of this book not only the term 'style,' but also the term 'stage.' This is consistent with the 3rd edition of the Manual for Faith Development Research, which was used for evaluation. But it is important to note that we associate with 'stage' not the entire set of structural-developmental assumptions, but rather understand 'stage' as synonymous with, or interpreted by, 'style.' In the 4th revised re vision (Streib \& Keller, 2018), we only use 'style' to turn to a consistent terminology.
} 
[89] The names of the religious styles largely correspond to Fowler's description of faith stages. And in the praxis of empirical research, the coding criteria in the Manual could be used for identifying the specific style. The slightly different names of religious styles nevertheless intend to put more emphasis on the inter-personal inter-action that make up a religious style. The faith development interview as a key research instrument and its structural evaluation are still considered valid, however, interpreted from a more comprehensive perspective on development. This allows us to account for variance in stage/style assignment, as the simultaneous presence of different styles is the rule rather than the exception.

On the basis of the religious styles model, we have developed the Religious Schema Scale (RSS, Streib, Hood, \& Klein, 2010) as a scale to be used in questionnaire research. Schemata thereby are conceptualized as constructs that are applied, like habitus, to interpret and deal with experiences. In respect to the religious styles, religious schemata may be regarded as indicators for a specific style. Thus, the schema truth of texts and teachings is considered indicative of the instrumental or do-ut-des religious style/the mythic-literal faith; the schema of fairness, tolerance and rational choice indicates the inviduative-systemic religious style/the individuative-reflective faith; and finally the schema of xenosophia/inter-religious dialog point toward the dialogical religious style/the conjunctive faith. The RSS also has a specific focus on the domain of inter-religious encounter and thus reflects three different ways of dealing with religious diversity. This is of particular interest in the context of the research presented in this book, as will be explained below.

The attentive reader will also discover that Fowler's Stage Six has no equivalent, but the number of religious styles is only five and ends with the dialogical style. We argue for this reduction to the elementary not only with reference to the empirical irrelevance of Fowler's Stage Six, but also because of philosophical and theological problems in Fowler's (1981) use of "universalism" in his understanding of universalizing faith - which made him slip into a particular theological interpretation (Stage Six as Kingdom of God) that he found very appealing and convincing.

It is exactly our reserve toward the conceptual closure that we see in Fowler's 'universalism,' which caused us to more modestly assume that openly dealing with paradox and the resistance of the alien is the best we can hope for in our fragmented world (see Chap. 1). Thus, and this is our next argumentative step in this chapter, dialog and xenosophia are regarded the top in the hierarchy of religious styles.

\section{Xenosophia-Top of the Developmental Hierarchy}

As noted in Chap. 1 already, there are correspondences between xenological patterns such as xenosophia and Fowler's faith stages and Streib's religious styles. These correspondences are all the more convincing when grounded in a philosophical conceptualization of xenosophia. Then, the differences between the religious styles rest on a solid foundation.

[90] 
Table 3.1 Correspondences of stage, styles, schemata with Xenological patterns

\begin{tabular}{l|l|l|l|l}
\hline $\begin{array}{l}\text { Faith stages } \\
\text { (Fowler, 1981) }\end{array}$ & $\begin{array}{l}\text { Religious styles } \\
\text { (Streib, 2001) }\end{array}$ & $\begin{array}{l}\text { Religious } \\
\text { schemata (Streib } \\
\text { et al., 2010) }\end{array}$ & $\begin{array}{l}\text { Inter-religious } \\
\text { negotiation } \\
\text { (Streib, 2006b) }\end{array}$ & $\begin{array}{l}\text { Xenological } \\
\text { patterns (see } \\
\text { Chap. 1) }\end{array}$ \\
\hline $\begin{array}{l}\text { Conjunctive } \\
\text { faith }\end{array}$ & Dialogical & $\begin{array}{l}\text { Xenosophia/ } \\
\text { inter-religieus } \\
\text { dialog }\end{array}$ & $\begin{array}{l}\text { Dialogical/ } \\
\text { inter-religious }\end{array}$ & Xenosophia \\
\hline $\begin{array}{l}\text { Individuative- } \\
\text { reflective faith }\end{array}$ & $\begin{array}{l}\text { Individuative- } \\
\text { systematic }\end{array}$ & $\begin{array}{l}\text { Fairness, } \\
\text { tolerance and } \\
\text { rational choice }\end{array}$ & $\begin{array}{l}\text { Explicitly } \\
\text { multi-religious }\end{array}$ & $\begin{array}{l}\text { Tolerance respect/ } \\
\text { esteem conception }\end{array}$ \\
\hline $\begin{array}{l}\text { Synthetic- } \\
\text { conventional } \\
\text { faith }\end{array}$ & Mutual & $\begin{array}{l}\text { Implicitly } \\
\text { multi-religious }\end{array}$ & $\begin{array}{l}\text { Tolerance/ } \\
\text { coexistence } \\
\text { conception }\end{array}$ \\
\hline $\begin{array}{l}\text { Mythic-literal } \\
\text { faith }\end{array}$ & $\begin{array}{l}\text { Instrumental- } \\
\text { reciprocal }\end{array}$ & $\begin{array}{l}\text { Truth of texts and } \\
\text { teachings }\end{array}$ & $\begin{array}{l}\text { Imperialistic } \\
\text { mono-religious }\end{array}$ & $\begin{array}{l}\text { Prejudice or } \\
\text { tolerance/ } \\
\text { permission } \\
\text { conception }\end{array}$ \\
\hline $\begin{array}{l}\text { Intuitive- } \\
\text { projective faith }\end{array}$ & Subjective & & $\begin{array}{l}\text { Xenophobic } \\
\text { mono-religious }\end{array}$ & Xenophobia \\
\hline
\end{tabular}

It was particularly the difference between xenosophia and tolerance that has opened the perspective in our discussion in Chap. 1. The sharper xenosophia came into focus with reference to the line of the philosophical reasoning of Waldenfels (2011) and Nakamura (2000), the sharper xenosophia stood out from 'tolerance' in all its conceptions detailed by Forst (2013) and, of course, from prejudice and xenophobia. As distinctive characteristics of xenosophia, we have noted: the responsive reaction to the alien, the non-hermeneutical reservation in all attempts of understanding the alien, and not shutting the door against the resistance and irritation of the alien. Specific to xenosophia is also the potential surplus of creativity and wisdom.

From these characteristics of xenosophia, it is obvious that there is a correspondence with Fowler's Stage Five of conjunctive faith, Streib's dialogical religious style, and the religious schema of xenosophia/inter-religious dialog. And this also suggests a hierarchical difference to Fowler's Stage Four of individuative-reflective faith and the related religious style and schema.

Now in this chapter, we take perspective from the other side, from the developmental models, and flesh out the consequences of placing xenosophia on the top of the hierarchy. Table 3.1 is an attempt to associate faith stages, religious styles, religious schemata and xenological patterns. Table 3.1 also includes the association with inter-religious negotiation styles, as noted earlier by Streib (2005b, 2006).

It should be noted, however, that the two columns on the right in Table 3.1 present attitudes that apply the styles (two columns on the left) and the schemata (in the middle) to the domain of inter-religious and inter-cultural relations. This is particularly important in the thematic framework of this book. We should keep in mind 
[91] however that, as indicated by the variety of Fowler's aspects, the faith stages/religious styles cover more ground, i.e. include more domains such as the understanding of texts and symbols, the social horizon for one's identity, or the ways of symbolizing one's experiences of transcendence, to name a few.

But for the context of our discussion in the book, it is important to note that xenosophia is a feature of Stage Five of conjunctive faith (Fowler) and the dialogical religious style (Streib), and thus stands on the top of the hierarchy of xenological styles. This hierarchy is reflected in developmental trajectories, even if the "logic of development" is open to empirical enquiry.

\section{The Faith Development Interview and its Evaluation}

In view of his broad and comprehensive concept of 'faith,' it is completely understandable that Fowler could not imagine a quantitative measure for 'faith' and has opposed any pencil and paper test, but instead from the beginning has opted for an interview approach, as is documented already in the first edition of the Manual for Faith Development Research (Moseley, Jarvis, \& Fowler, 1986).

\section{The Faith Development Interview}

Research in faith development, according to Fowler, is based on a semi-structured interview, the Faith Development Interview (FDI). An interview takes between thirty minutes and two hours. In the FDI, twenty-five questions are asked that are divided in four sections: first, respondents are invited to reflect on their lives (life tapestry/life review), then, in a second section, on their relationships past and present, in a third section on their values and commitments, and only in the last section on religion and world view. Interview questions are presented in full length in Table 3.2. ${ }^{2}$ Interviewees respond by presenting, explaining or justifying their opinions. It is however a special characteristic of the FDI that respondents - motivated by the autobiographical questions at the beginning of the interview process respond by reporting events and by telling stories and autobiographical narratives.

\footnotetext{
${ }^{2}$ We present the version of the FDI questions (follow-up questions are in brackets) as used in our current research. In this version, some questions, as they are presented in the Manual for Faith Development Research (also in the 3rd edition: Fowler, Streib, \& Keller, 2004), have been slightly modified in order to be more inclusive in regard to the variety of religious traditions and worldviews; for example, in question 20 , the adjectives "spiritual" and "faithful" have been added; or in question 4, "image of God and relation to God" has been exchanged by "world view" in the main question, and the phrase "image of God and the Divine" has been moved to a follow-up question.
} 
Table 3.2 The faith development interview questions

LIFE TAPESTRY/LIFE REVIEW

1. Reflecting on your life thus far. Identify its major chapters. (If your life were a book, how would you name the different chapters? What marker events stand out as especially important?)

2. Are there past relationships that have been important to your development as a person?

3. Do you recall any changes in relationships that have had a significant impact on your life or your way of thinking about things?

4. How has your world view changed across your life's chapters? (How has this affected your image of God or of the Divine? What does it mean to you now?)

5. Have you ever had moments of intense joy or breakthrough experiences that have affirmed or changed your sense of life's meaning? (What are they? How have these experiences done so?)

6. Have you experienced times of crisis or suffering in your life? (Have you experienced times when you felt profound disillusionment, or that life had no meaning?)

RELATIONSHIPS

7. Focusing now on the present, how would you describe your parents and your current relationship to them? (Have there been any changes in your perceptions of your parents over the years? If so, what caused the change?)

8. Arc there any other current relationships that are important to you?

9. What groups, institutions, or causes, do you identitv with? (Why are they important to vou?)

\section{PRESENT VALUES AND COMMITMENTS}

10. Do you feel that your life has meaning at present? (What makes your life meaningful to you?)

11. If you could change one thing about yourself or your life, what would you most want to change?

12. Are there any beliefs, values, or commitments that seem important to your life right now?

13. When or where do you find yourself most in communion or harmony with the universe?

14. What is your image or model of mature faith, of a mature response to questions of existential meaning?

15. When you have an important decision to make, how do you generally go about making it? (Can you give me an example? If you have a very difficult problem to solve, to whom or what would you look for guidance?)

16. Do you think that actions can be right or wrong? (If so, what makes an action right in your opinion? What makes an action wrong?)

17. Are there certain actions or types of actions that are always right under any circumstances? (Are there certain moral opinions that you think everyone should agree on?)

RELIGION AND WORLD VIEW

18. Do vou think that human life has a purpose? (If so, what is it? Is there a plan for our lives, or are we affected by a power or powers beyond our control?)

19. What does death mean to you? (What happens to us when we die?)

20. Do you consider yourself a religious, spiritual or faithful person?

21. Are there any religious, spiritual or other ideas, symbols or rituals that are important to you, or have been important to you?

22. Do you pray, meditate, or perform any other spiritual discipline?

23. What is sin to your understanding?

24. How do you explain the presence of evil in our world?

25. If people disagree about issues of world view or religion, how can such conflicts be resolved? 
[93] The very first question in the FDI invites the respondent to engage in this kind of structured autobiographical reconstruction. This reflects Fowler's strong emphasis on autobiographical reconstruction, which should be elicited by the FDI. ${ }^{3}$

\section{Structural Evaluation of the Faith Development Interview}

Consistent with the broad construct of 'faith,' faith development interview evaluation is characterized as a hermeneutical adventure:

Administering and coding the faith development interview is an exercise in hermeneutics. Language, in the form of verbal response to questions, is the observable datum upon which the interviewer/coder bases inferences about the mental and emotional processes of the person being interviewed. In order to do this, the interviewer must interpret these verbal responses and reconstruct them in terms of structural developmental theory. (Moseley et al., 1986, p. 16).

As this quote, which was included already in the first edition of the Manual for Faith Development Research, demonstrates, faith development interview evaluation decisively opts for an interpretative openness. But this quote also restricts openness: Immediately it is suggested to focus the interpretative attention to the cognitivedevelopmental structures. An underlying faith structure is considered the central object of evaluation, while thematic contents such as knowledge, assent to a statement of belief, or report of a practice are regarded to be surface phenomena. Thus, this quote demonstrates how the account for hermeneutical diversity is channeled immediately on the "reconstruction in terms of structural developmental theory."

Evaluating a FDI thus implies to discern a supposedly stable pattern of faith, whose development is seen as "change that eventuates in increasingly complex structures" (Moseley et al., 1986, p. 3). Certainly, identifying the structures, which may or may not be conscious to the interviewee, is an interpretation. The question however is whether this interpretation fully reflects the diversity and multidimensionality of faith.

Anyway, evaluating a FDI for structure proceeds in rating the responses to the 25 FDI questions in the interview transcript by comparing them with descriptions in the respective section in the Manual. After eventually comparing the coding criteria of one stage above and/or one stage below, the evaluator decides for a faith stage to be assigned to that specific passage in the interview. The evaluator then notes this stage assignment, together with the position in the transcript and a brief note for justification of the faith stage assignments, in a scoring sheet (see Fowler, Streib, \& Keller, 2004, p. 77, for an example).

\footnotetext{
${ }^{3}$ Field work with the FDI in 1970s and 1980s even used the so-called "Life Tapestry Exercise" (see Fowler, Streib, \& Keller, 2004, p. 69), a paper with several columns (calendar year; age; geographic and socio-economic place, key relationships; uses and directions of self; marker events; events in society; images of God; value centers; authorities). The respondents were asked to fill this out prior to the interview. The interviewee and the interviewer had the "Life tapestry sheet" in front of them in many interviews. And even when we do not use the "Life Tapestry Exercise" anymore, autobiographical reflection and autobiographical narration are triggered in the FDI.
} 
[94] The total FDI score is calculated, according to the Manual, using a simple for- mula: add all faith stage assignment for the single responses and divide them by the frequency of assignments and eventually round the decimals to integral numbers to indicate the faith stage.

\section{Accounting for Variance in Structural Evaluation}

Our revisions of research with the faith development interview are based on the experience accumulated in Bielefeld research projects, ${ }^{4}$ in particular in the Study on Deconversion (Streib, Hood, Keller, Csöff, \& Silver, 2009), the Study on the semantics and psychology of "Spirituality" (Streib \& Hood, 2016a), and the current longitudinal study on religious styles development. ${ }^{5}$ In preparing field work for the Deconversion Study, the 3rd edition of the Manual for Faith Development Research (Fowler et al., 2004) has been completed. Advancements in the 3rd edition will be detailed below (see also Keller \& Streib, 2013; Keller, Klein, \& Streib, 2013; Streib, Wollert, \& Keller, 2016; Keller, Coleman, \& Silver, 2016). ${ }^{6}$

The "classical" structural evaluation of the FDI has been carefully modified to allow more openness for diversity in stage assignments to the single FDI questions. This also includes attention to the potential differences between the aspects of faith. Taking a simple average of the 25 scores originally was justified with reference to the assumption that stages are structural wholes in which all aspects are indicators with equal weight and develop synchronically-forming one plane horizontal heptagon without any difference in height, to allude to the visualization in Fig. 3.1. But also without this structural-developmental justification, we have used the calculation of a sum score to obtain a general estimate of the style. Ignored by this way of estimating the total FDI score however is the spread of stage assignments, which frequently is larger than one stage and may possibly indicate aspect-specific differences-eventually exceeding their possible interpretation as developmental time lags (décalage in the terms of Piagetian research).

It is not a new finding that faith stage assignments to the single FDI questions vary. The Manual, from the first edition on, has assumed some variance in stage assignments. But to do nothing else than averaging this variance leads to an implausible reduction of complexity. Since empirical data evidence differences in stage assignments of more than one stage as rule, rather than as exception, it may be wise to keep the door open to an interpretation of this variance. Our suggestion thus is the visualization of the faith stage assignments to the single FDI questions in figures

\footnotetext{
${ }^{4}$ With more than 900 FDIs, the Bielefeld Research Center for Biographical Studies in Contemporary Religion has the privilege of owning a considerable FDI data base (probably the largest in the world) with considerable cross-cultural and cross-religious diversity.

${ }^{5}$ See our website for this project at http://www.uni-bielefeld.de/religiousstylesdevelopment/

${ }^{6}$ In the meantime, we have completed the 4th revision of the Manual (Streib \& Keller, 2018) and recommend this for future use in research with the FDI.
} 


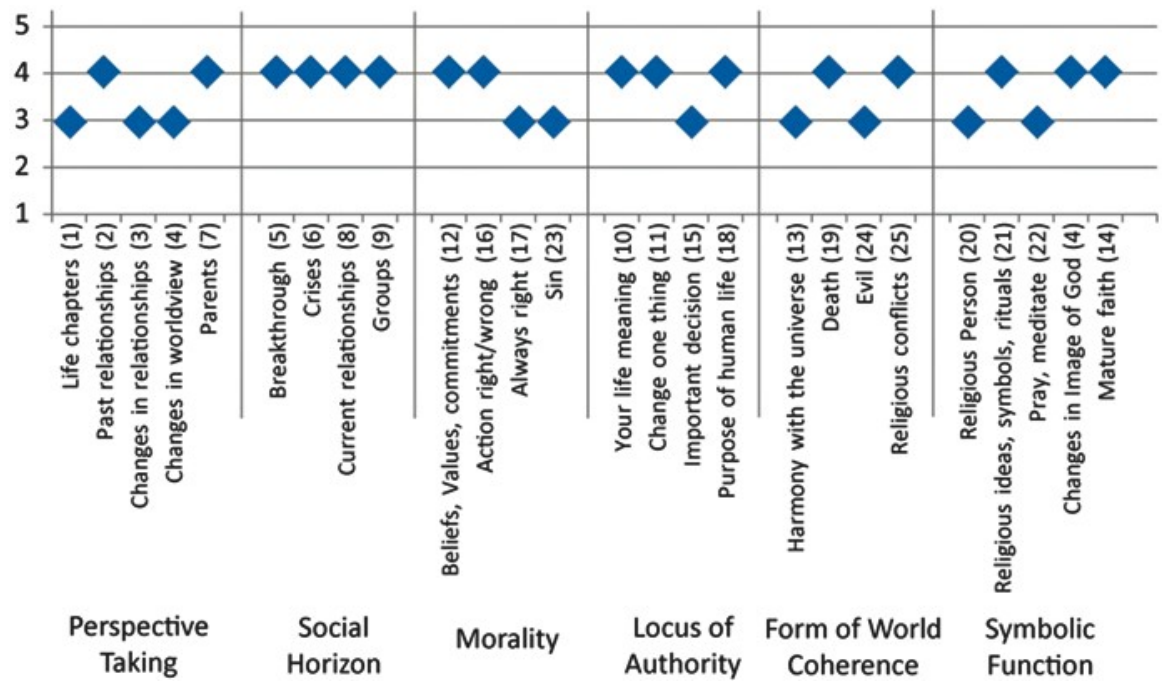

Fig. 3.3 The stage assignments to the single FDI questions in the interview with Nina

[95] that we call stage-aspect maps. The case studies in this book include such a stage- aspect map. Figure 3.3 is an example from the case study in Chap. 12.

This detailed attention to the stage assignments of the single responses to the 25 FDI questions opens the evaluation for important new questions. It enables the account for the aspect-specific stage assignments. The stage-aspect map also allows for an estimation of the FDI total score, based on the majority of assignments of a certain stage. From Fig. 3.3 it is obvious that Nina's total FDI score has to be estimated Stage Four. But from this general tendency to Stage Four in Nina's answers, the question arises: What do her Stage Three answers indicate? Furthermore, the stage-aspect map may allow for a new way of analyzing the FDI, when the responses are sorted according to questions for religious or non-religious themes?

Taken together, accounting for more variance of the stage assignments opens the structural evaluation beyond identifying and justifying the final FDI sum score for the interpretation of differences in style preferences that may be aspect-specific or domain-specific.

\section{The Inclusion of Narrative Analysis}

Consistent with the recognition of greater complexity and diversity in the religious styles perspective, the FDIs should be evaluated not only in cognitive-structural terms, but in a decisive qualitative approach accounting for narratives and a variety of content dimensions, as suggested by Streib (2005). Thus, special attention is 
Table 3.3 Structure of a narrative according to Labov and Waletzky (1967)

\begin{tabular}{l|l}
\hline Orientation & Provides background such as antecedents, place, time and persons \\
\hline $\begin{array}{l}\text { Complication } \\
\text { Evaluation/attempts } \\
\text { to solve }\end{array}$ & Central event that breaks with normality, elicits an emotion, defines a goal \\
\hline Resolution & $\begin{array}{l}\text { Successful or not successful result of attempts to solve complication / } \\
\text { adjust evaluation }\end{array}$ \\
\hline Coda & Signals end, leads back to the present \\
\hline
\end{tabular}

[96] given to the narratives in the FDIs, which is manifest in a focus on life review and on especially revealing ("hot") narrative segments in the FDI.

When people are asked to look back and reflect on their lives, they do several things: They give information, reporting, explaining and accounting for what happened. In each of the sections of the FDI we receive such information, respondents also spontaneously develop thoughts as they talk about their experiences or the philosophies they have been living with and want to share. When people are revealing something important about themselves, they often tell a story - which points to some importance: What makes an experience worth telling? What makes it special? The linguist Labov has collected many narratives and names in his recent book (Labov, 2013, p. 4), "three universal centers of interest: death, sex and moral indignation."

A variety of narratives are invited by FDI questions which explore, in biographical perspective, life review, relationships, values and commitments, and religion and world view. Throughout the interviews, we look for narratives as defined by Labov and Waletzky (1967), little stories consisting of orientation, complication, evaluation, resolution, and coda. These narratives, stories worth telling, will point to important aspects of religious experience and identity. Table 3.3 illustrates the structure of such a story, according to Labov and Waletzky, modified by Habermas and Berger (2011).

After having identified a narrative and ordered according to this pattern, we add a title telling what it is all about. In some cases narrators announce this themselves, sometimes giving an abstract which informs about the point to be made (cf. Habermas \& Berger, 2011). Noting titles of stories across interviews will support the exploration of the FDI as an instrument which elicits narratives (Keller, Coleman, \& Silver, 2016).

\section{The Evaluation of Content Dimensions}

Evaluation of the FDI may also consider content dimensions that are influential for religious development. How do we evaluate these contents? We summarize statements and contentions and use concepts like attachment, mentalization, moral foundations, and wisdom to structure interview content in the four sections of the FDI. These explore life review, relationships, values and commitments, and religion and worldview (see Table 3.2, for the FDI sections). 
[97] The Life Review section, starting with the question of dividing one's life into chapters, invites autobiographical narrative and reflection. Next, Relationships are explored. This section can be evaluated drawing on current concepts like attachment and mentalization which take into consideration how persons reconstruct relation- ship experiences and their concepts of their own and others' inner lives. The ques- tions in Present Values and Commitments ask for information on social engagement and on central convictions and moral orientation. The fourth section of the FDI covers Religion and Worldview. Here, we explore the "spiritual," religious or worldview-related selfidentification respondents give in the context of telling and reflecting on their development as they see it. Also, issues transcending one's per- sonal existence are addressed, as well as religious or ideological conflict. How respondents handle such conflict is explored by drawing on research and concepts from the study of wisdom. Wisdom or rather "wisdom-related knowledge" was introduced into empirical psychology to get access to culturally based aspects of cognitive development across the adult life span (Dittmann-Kohli \& Baltes, 1990). In the next paragraphs, we give a more detailed outline of the four sections of the FDI and the evaluative perspectives we use. We have explored ratings of "proxies" of e.g. mentalization, attachment and wisdom, using scales of their respective dimensions in our new scoring sheet which we use for documenting and processing FDI ratings. These different perspectives will be drawn together for the interpretation of the cases. And we use these four sections also for structuring case studies.

\section{Life Review: Life Chapters and Autobiographical Reasoning}

The first section of the FDI focuses on life review, resembling the "life chapter task" of the research programs of McAdams (1990, 1993, McAdams, Josselson, \& Lieblich, 2001). Also, comparable to high and low points, as in the format used by McAdams and his team, experiences of crisis and of intense joy are addressed. Worldview and images of the divine are introduced as potentially important areas of development, to be taken up again in further sections of the FDI. The life review section, especially the question probing for one's life's chapters, invites biographical reconstructions. This allows for the construction of indicators of structure and coherence which we have added to the scoring of the aspects of faith.

When working with the FDI as a narrative, we also turn to the specific contents which are offered as answer to the "life chapter question" and use these to reconstruct the individual biographies. The first step consists in the reconstruction of the trajectory presented by the chapters named. Some respondents offer these in a chronological order, using conventional structures and ordered according to cultural concepts of biography (Habermas, 2010). Others prefer a different structure, sometimes based on very specific labels for their lives' chapters. We rearrange the chapters mentioned according to timeline, noting the structuring strategy of the person. Also, we note themes addressed. We will return to this "abstract" when we have worked through the interview to compare it with the trajectory as it unfolded. 
[98] Did the respondent cover what was announced? Where there surprising revelations? This supports our understanding of the dynamics of the interview.

We also draw on McAdams' work for the identification of typical narrative patterns (redemption vs. contamination). For exploring links between self and (religious) experience, we build on the methods suggested by McAdams (1993; Pasupathi, Mansor, \& Brubaker, 2007), thus identifying "religious identity narratives" (self-defining narratives of religious experience).

\section{Relationships: Probing into Attachment, and Reflective Functioning}

The Relationships section of the FDI elicits narratives of personal relationships as currently experienced. With questions for changes in relationships, and inviting reflections on possible causes for changes this section shows affinity to the Adult Attachment Interview (AAI, Main, Hesse, \& Kaplan, 2005). We take this as encouraging exploration with AAI-derived concepts and measures such as attachment style and reflective functioning.

Turning to content in the Relationships section, we note: Who is named as important? Do these persons belong to the interviewee's family, are they friends, colleagues, teachers with which the interviewee has or had a personal relationship? Are other persons mentioned, such as public figures of influence? To what life phases do persons mentioned belong? For interpretation, we turn to two concepts anchored in research on attachment to use the dimensional perspectives they offer. Both have been used as gradual measures in our evaluation procedure: attachment (style) and mentalization (mode).

Thus, the FDI, probing into relationships, allows the assessment of a proxy for attachment, and to establish ratings of secure vs. insecure attachment. We have used the taxonomy introduced by Bartholomew and Horowitz (1991) to guide our ratings (and note them in our scoring sheet). Based on combinations of a person's selfimage (positive or negative) and image of others (positive or negative), four attachment prototypes are defined: Persons who have a positive image of themselves and others are supposed to have a secure attachment style and to feel comfortable with intimacy and with autonomy. They should be open to discussion of relationship and attachment, displaying a realistic forgiving perspective, and vivid descriptions of relationships. Insecurely attached persons with a negative view of themselves and a positive view of others are supposed to be preoccupied with relationships, and to make great efforts to gain attention and support and to show indications of low selfesteem. The insecurely attached persons with a positive view of themselves and a negative view of others are supposed to be dismissive of intimacy. They are expected to stress independence, emotional distance, and to downplay rejections. The fearful (disorganized) type has a negative view on self and on others and should show negative attitudes and distrust toward self and others. 
[99] Mentalization is another concept connected to the study of retrospective accounts of relationship experience and based on the evaluation of the AAI. Mentalization has been defined as "the mental process by which an individual implicitly and explicitly interprets the actions of himself or herself and others as meaningful on the basis of intentional mental states such as personal desires, needs, feelings, beliefs, and reasons" (Bateman \& Fonagy, 2004). Mentalization has also been described as "holding mind in mind", "attending to mental states in self and others", "under- standing misunderstandings", "seeing yourself from the outside and others from the inside", and as "giving a mental quality to or cultivating mentally" (Allen, Fonagy,

\& Bateman, 2008, p. 3). Mentalization refers to a reflective stance which attends to inner states. The measure of mentalization which is used in most studies, the Reflective Functioning Scale, has first been developed as an AAI-subscale (Fonagy, Target, Steele, \& Steele, 1998). The operationalization of the proxy we created for our evaluation makes use of these basic criteria of Fonagy et al.'s Manual: Awareness of the nature of mental states; The explicit effort to tease out mental states underlying behavior; Recognizing developmental aspects of mental states; Mental states in relation to the interviewer.

\section{Present Values and Commitments: Moral Reasoning, Moral Foundations?}

The third section of the FDI, Values and Commitments, explores the wider social context of groups and of concerns respondents engage with, of values and norms as they perceive and negotiate them. We note content, that is, individual descriptions and examples of the concerns in which they invest themselves, and how they do that. We also note their current values and commitments as stated. We note what gives their lives meaning, and explore domains of counterfactual thinking. We list moral convictions (right vs. wrong), including examples, if these are given.

This section offers much information for the FDI rating of the aspect of moral judgment, which is based on Kohlberg's conception of moral reasoning. Recent discussion has referred to the development of the "moral personality" versus "moral intuitions" (Haidt \& Graham, 2007; Narvaez \& Lapsley, 2009). Both approaches explore morality as encompassing more than moral judgment and embedded in more complex contexts. The model put forward by Haidt and Graham offers descriptive categories for their "moral foundations," which are applicable to the accounts elicited in this section of the FDI: harm/care, fairness/reciprocity, in-group/loyalty, authority/respect, and purity/sanctity. They argue that the "moral domain" charted by research inspired by Kohlberg and Gilligan focused on justice and care, but neglected community-related orientations such as loyalty to one's own group, respect for authority, and purity and sanctity. The anthropological foundation may be debatable; the categories themselves have been shown to differentiate between liberals, who endorse harm/care and fairness/reciprocity, and conservatives, who 
[100] also endorse the additional three. Also, the notion of moral intuition raises interest- ing questions with respect to moral behavior: Is this guided by deliberate moral reasoning and / or spontaneous intuition? Therefore, for the exploration of a more encompassing concept of morality, we suggest to complement the original approach by drawing on the taxonomy developed by Haidt and Graham. Different moral atti- tudes may go along with different selfidentifications.

\section{World Views and Religion: Transcendence and Wisdom}

In this fourth section, respondents explain their religious identity as they understand it in the context of their images of the transcendent. They are invited to describe their religious or spiritual practices, take their stance toward traditional religious concepts, and display their ideas on the boundaries of human existence and understanding - and on what may lie beyond. Also, they are asked how religious conflicts or conflicts due to different world views might be resolved. Evaluating the content of this section, we attend to the self-identification with respect to religion and world view. We document rituals reported. Also, we note ideas of afterlife or the rejection of such ideas. Addressing the conditions and limits of human existence, of one's own existence, stimulates fears as well as wishes and longings. These are sometimes mixed and conflicted - and their sometimes tentative formulations deserve attention and careful interpretation.

The content dimension in this last section of the FDI suggests an interpretation in terms of 'wisdom.' 'Wisdom' can be understood as linking the cognitive component of faith development with a current concept. Wisdom has been suggested as secular successor of religion (Baltes, 2004) — which makes it an interesting candidate in a faith development research context that is based on Fowler's broad concept of faith. Wisdom, or rather wisdom-related knowledge, has been defined as an expert knowledge system "dealing with the fundamental pragmatics of life," and introduced as an option to explore culture-based aspects of cognitive development across the adult life span (Dittmann-Kohli \& Baltes, 1990).

The FDI question of how religious or world view conflicts might be resolved may be especially qualified as proxy of "wisdom-related behavior." Here, we can add content to the ratings in our evaluation and describe in what domains of their lives respondents show wisdom-related behavior, drawing on the criteria as suggested by the Berlin paradigm (Staudinger, Smith, \& Baltes, 1994):

(1) rich factual knowledge about the fundamental pragmatics of life (indicated by a wide variety of themes and depth);

(2) rich procedural knowledge about dealing with the fundamental pragmatics of life (indicated by e.g. the ability to systematize and to analyze past experiences and to apply this knowledge); [101] 
(3) life-span contextualism: understanding of life contexts and their temporal (developmental) relations (indicated by consideration of age-related, cultural and biographical contexts);

(4) value-relativism: knowledge about the differences in values and life goals (indicated by decentralization, the ability to distance oneself from personal values, and value related relativism while accepting universal values);

(5) uncertainty: knowledge about the relative uncertainty of life and its management (indicated e.g. by awareness of unexpected individual or social events and developments).

From the discussion about xenosophia, we may regard the identification of wisdom of special interest for our evaluation of the interviews. We need, however, be careful enough as to recognize the differences between the concept of wisdom in 'xenosophia' and wisdom in terms of the Berlin paradigm. Nevertheless, we may suggest that the response to the experiences of the alien, which does not foreclose irritation and resistance, corresponds to some of the positive features identified in above criteria for wisdom-related behavior. This may enrich our interpretation of paths to xenosophia.

\section{Triangulation with Questionnaire Data}

The structural, narrative and content analyses open a broader perspective in the interpretation of the FDIs. But there is even more potential in our research design: Since the interviewees have participated in our questionnaire, we have more data from them that may go into the interpretation of the cases. Relating various perspectives of the interview interpretation to these quantitative data is part of the triangulation which our research design includes. For the purpose of a demonstration, we present the table (Table 3.4) comparing the scores of Nina F. on the most important scales in the questionnaire with her quadrant group.

Of course, triangulating in our research consists in data exchange in both directions: from the FDI evaluation into the quantitative data set, and from the quantitative data set to the single case interpretation. The import of FDI results into the quantitative data set has allowed conducting statistical analyses.

The other direction of triangulation can be seen in the case studies of this book. For each case study, we have produced a table such as Table 3.4. On the basis of such comparison, the FDI evaluation is opened up for more comprehensive interpretation and cross-validation. Ultimately, these comparisons feed into the interpretation of the case studies and profile the case in the context of the quantitative results. 
Table 3.4 Comparison of Nina F. with respective quadrant group on the most important scales in the questionnaire

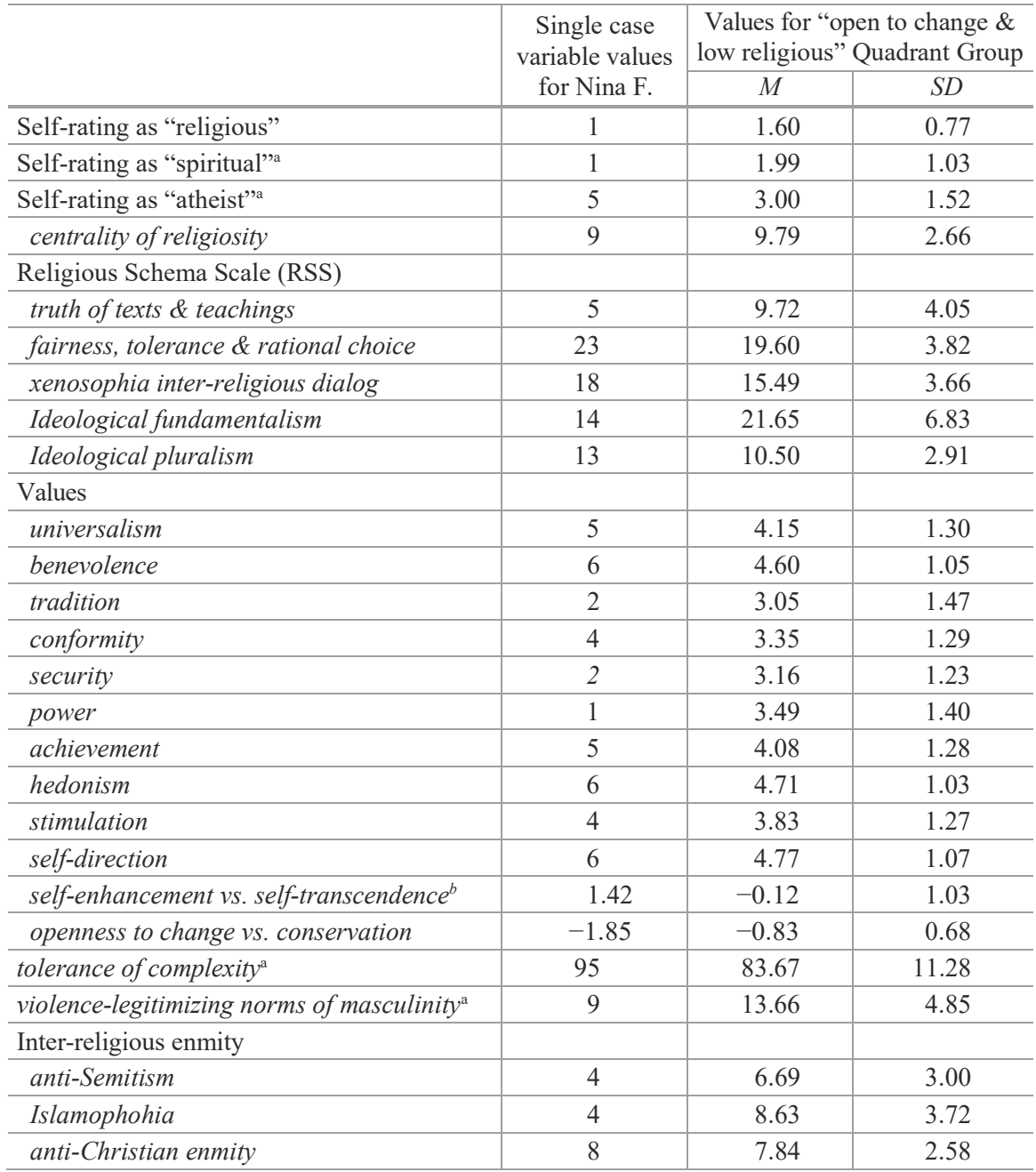

Note All comparisons have been calculated with age cohorts, sex. and cultural and economic capital being controlled. Analyses for the Quadrant 1 group are based on $n=485$ cases

${ }^{a}$ Analysis based on smaller sample size $(n=466)$. because variables have not been included in the pilot study (see Chap. 4)

${ }^{\mathrm{b}}$ The factor scores for the two value axes self-enhancement $v$ s. self-transcendence and openness to change vs. conservation are z-standardized, i.e. their means are adjusted to 0 and their standard deviations are adjusted to 1. The factor score values for the axes are the same as in Fig. 9.7 of Chap. 9 and correspond to the way the value space is usually constructed. This means that negative values express value orientations toward more self-enhancement on the first axis or toward more openness to change on the second axis, while positive values indicate value orientations toward more self-transcendence (first axis) or toward more conservation (second axis) 


\section{Case Study Reconstruction-Biographical Paths to Xenosophia}

[103] The FDI was designed by Fowler and applied, in the early times of faith develop- ment research, as a kind of stand-alone measure for the search and presentation of evidence for the new and, for the time, spectacular hypothesis that there $i s$ develop- ment in faith over the adolescent and adult life-span. The 359 FDIs which Fowler and his research teams in Harvard and Atlanta have conducted and evaluated and Fowler (1981) was able to present, were primarily aimed at providing such evidence.

In subsequent research-Fowler's faith development theory has inspired over 70 research projects, a majority of which were studies using the FDI (see Streib 2003c, for a review) - new aims for the FDI have emerged. Specific groups and specific challenges came into focus, such as, to note a few, development in adolescence, formation and learning in higher education, the status of and potential promotion of faith development in congregations, career satisfaction of clergy, coping with terminal illness such as HIV infection and coping with death.

Some exceptions notwithstanding, the general focus of research with the FDI did only marginally include cross-cultural and cross-religious - not to speak of longitudinal-perspectives. Also marginalized was the assessment of faith development/ religious styles in the context of new forms of religious phenomena which have emerged in the religious field and would deserve attention.

In this context of faith development research, we have attempted to cover new ground already in previous research: We have related deconversion to faith development (Streib et al., 2009); we have extended this focus to the new phenomenon in the religious field which is associated with a self-attribution of "spirituality." In the research presented in this book, we have investigated faith development in relation to xenosophia and xenophobia. The principal aim of including the FDI in research thus is our interest in a "thick description" of biographical, moral and socialcontextual embeddedness of xenosophia.

The FDI invites remembering, reasoning and narrating about biography, relationships in past and present, values and commitments, and on religion and world view. Thus the FDI questions guide an interview which invites the interviewee to wander through the variety of essential domains and biographical epochs in his or her life. Taken together, we used the FDI with the aim of generating a wealth of autobiographical narratives and reflections on a broad variety of life themes. The case studies in the case study chapters of this book are the proof that this methodological decision was not mistaken. 


\section{References}

Allen, J. G., Fonagy, P., \& Bateman, A. W. (2008). Mentalizing in clinical practice. Washington, DC: American Psychiatric Publishing.

Baltes, P. B. (2004). Wisdom as orchestration of mind and virtue, online at: library.mpib-berlin. mpg.de.

Bartholomew, K., \& Horowitz, L. (1991). Attachment styles among yound adults: A test of a fourcategory model. Journal of Personality and Social Psychology, 61, 226-244.

Bateman, A., \& Fonagy, P. (2004). Mentalization-based understanding of borderline personality disorder. In A. Bateman \& P. Fonagy (Eds.), Psychotherapy for borderline personality disorder. Mentalization-based treatment (pp. 55-109). New York: Oxford University Press.

Cantwell Smith, W. (1963). The meaning and end of religion. Minneapolis: Fortress Press. 1991.

Cantwell Smith, W. (1979). Faith and belief. Princeton, NJ: Princeton University Press.

Dittmann-Kohli, F., \& Baltes, P. B. (1990). Toward a Neofunctionalist conception of adult intellectual development: Wisdom as a prototypical case of intellectual growth. In C. N. Alexander \& E. J. Langer (Eds.), Higher stages of human development. Perspectives on adult growth (pp. 54-78). New York: Oxford UP.

Fonagy, P., Target, M., Steele, H., \& Steele, M. (1998). Reflective-functioning manual version 5 for application to adult attachment interviews. London: University College London.

Forst, R. (2013). Toleration in conflict: Past and present. Cambridge: Cambridge University Press.

Fowler, J. W. (1980). Faith and the structuring of meaning. In C. Dykstra \& S. Parks (Eds.), Faith development and Fowler (pp. 15-42). Birmingham: Reigious Education Press. 1986.

Fowler, J. W. (1981). Stages of faith. The psychology of human development and the quest for meaning. San Francisco, CA: Harper\&Row.

Fowler, J. W. (1996). Faithful change. The personal and public challenges of postmodern life. Nashville, TN: Abingdon Press.

Fowler, J. W., Streib, H., \& Keller, B. (2004). Manual for faith development research ( $3^{\text {rd }}$ ed.). Bielefeld/Atlanta: Research center for biographical studies in contemporary religion/Center for research in faith and moral development, Emory University.

Habermas, T. (2010). Autobiographical reasoning: Arguing and narrating from a biographical perspective. New Directions for Child and Adolescent Development, 131, 1-17.

Habermas, T., \& Berger, N. (2011). Retelling everyday emotional events: Condensation, distancing, and closure. Cognition \& Emotion, 25, 206-219.

Haidt, J., \& Graham, J. (2007). When morality opposes justice: Conservatives have moral intuitions that Liberlas may not recognize. Social Justice Research, 20, 98-116.

Keller, B., \& Streib, H. (2013). Faith development, religious styles and biographical narratives: Methodological perspectives. Journal of Empirical Theology, 26, 1-21. https://doi. org/10.1163/15709256-12341255.

Keller, B., Klein, C., \& Streib, H. (2013). Das Interview zur Glaubensentwicklung: Zur Exploration von Spiritualität im psychotherapeutischen Setting. Spiritual Care, 2, 35-43.

Keller, B., Coleman, T. J., \& Silver, C. F. (2016). Narrative reconstruction and content analysis in the interpretation of "spiritual" biographical trajectories for case studies. In H. Streib \& R. W. Hood (Eds.), Semantics and psychology of "spirituality". A cross-cultural analysis (pp. 251271). Cham, Heidelberg, New York, Dordrecht, London: Springer International Publishing Switzerland.

Kohlberg, L. (1984). Essays on moral development, Vol.II. The psychology of moral development. San Francisco: Harper\&Row.

Kohlberg, L., Levine, C., \& Hewer, A. (1983). The current formulation of the theory. In L. Kohlberg (Ed.), Essays on moral development, Vol.II. The psychology of moral development (pp. 212 319). San Francisco: Harper\&Row. 1984.

Labov, W. (2013). The language of life and death. The transformation of experience in oral narrative. Cambridge; New York: Cambridge UP. 
Labov, W., \& Waletzky, J. (1967). Narrative analysis: Oral versions of personal experience. In J. Helms (Ed.), Essays on the verbal and visual arts (pp. 12-44). Seattle: University of Wahsington Press.

Loevinger, J. (1976). Ego development: Conceptions and theories. San Francisco: Jossey-Bass.

Main, M., Hesse, E., \& Kaplan, N. (2005). Predictability of attachment behaviour and representational processes at 1, 6, and 18 years of age: The Berkeley longitudinal study. In K. E. Grossmann, K. Grossmann, \& E. Waters (Eds.), Attachment from infancy to adulthood (pp. 245-304). New York: Guilford Press.

McAdams, D. P. (1990). The person. An introduction to personality psychology. San Diego: Harcourt Brace Jovanovich.

McAdams, D. P. (1993). The stories we live by: Personal myths and the making of the self. New York: Guilford Press. 1997.

McAdams, D. P., Josselson, R., \& Lieblich, A. (Eds.). (2001). Turns in the road - narrative studies of lives in transition. Washington, DC: American Psychological Association.

Moseley, R. M., Jarvis, D., \& Fowler, J. W. (1986). Manual for faith development research. Atlanta: Center for Faith Development, Emory University.

Nakamura, Y. (2000). Xenosophie: Bausteine für eine Theorie der Fremdheit [Xenosophia. Building blocks for a theory of the alien]. Darmstadt: Wissenschaftliche Buchgesellschaft.

Narvaez, D., \& Lapsley, D. K. (2009). Moral identity, moral functioning, and the development of moral character. In D. M. Bartels (Ed.), Moral judgment and decision making (pp. 237-274). Amsterdam: Elsevier Academic Press.

Niebuhr, H. R. (1943). Radical monotheism and western culture. New York: Harper\&Row. 1960.

Pasupathi, M., Mansor, E., \& Brubaker, J. R. (2007). Developing a life story: Constructing relations between self and experience in autobiographical narratives. Human Development, 50, $85-110$.

Staudinger, U. M., Smith, J., \& Baltes, P. B. (1994). Manual for the assessment of wisdom-related knowledge. In Materialien aus der Bildungsforschung; 46. Berlin: Max-Planck-Inst. für Bildungsforschung.

Streib, H. (1991). Hermeneutics of metaphor, symbol and narrative in faith development theory. Ph.D. dissertation (Emory University). European university studies, Ser.23, Vol.408, Frankfurt/M.: Peter Lang.

Streib, H. (2001). Faith development theory revisited: The religious styles perspective. The International Journal for the Psychology of Religion, 11, 143-158. https://doi.org/10.1207/ S15327582IJPR1103_02.

Streib, H. (2003a). Religion as a question of style: Revising the structural differentiation of religion from the perspective of the analysis of the contemporary pluralistic-religious situation. International Journal for Practical Theology, 7, 1-22.

Streib, H. (2003b). Variety and complexity of religious development: Perspectives for the $21^{\text {st }}$ century. In P. H. M. P. Roelofsma, J. M. T. Corveleyn, \& J. W. Van Saane (Eds.), One hundred years of psychology of religion. Issues and trends in a century long quest (pp. 123-138). Amsterdam: Free University Press.

Streib, H. (2003c). Faith development research at twenty years. In R. R. Osmer \& F. Schweitzer (Eds.), Developing a public faith. New directions in practical theology. Essays in honor of James. W. Fowler (pp. 15-42). St. Louis: Chalice Press.

Streib, H. (2005a). Faith development research revisited: Accounting for diversity in structure, content, and Narrativity of faith. The International Journal for the Psychology of Religion, 15, 99-121. https://doi.org/10.1207/s15327582ijpr1502_1.

Streib, H. (2005b). Wie finden interreligiöse Lernprozesse bei Kindern und Jugendlichen statt? Skizze einer xenosophischen Religionsdidaktik [How do process of inter-religious take place in children and adolescents? Outline of a Xenosophic religious education]. In P. Schreiner, U. Sieg, \& V. Elsenbast (Eds.), Handbuch interreligiöses Lernen (pp. 230-243). Gütersloh: Gütersloher Verlagshaus. 
Streib, H. (2006). Strangeness in inter-religious classroom communication: Research on the 'Giftto-the-Child' material. In D. Bates, G. Durka, \& F. Schweitzer (Eds.), Education, religion and society. Essays in honour of John M. Hull (pp. 191-204). London: Rouledge.

Streib, H. (2007). Faith development and a way beyond fundamentalism. In C. Timmerman, D. Hutsebaut, S. Mels, W. Nonneman, \& W. van Herck (Eds.), Faith-based radicalism: Christianity, Islam and Judaism between constructive activism and destructive fanaticism (pp. 151-167). Brussels: P.I.E.-Peter Lang.

Streib, H. (2013). Conceptualisation et mesure du développement religieux en termes de schémas et de styles religieux - Résultats et nouvelles considérations. In P.-Y. Brandt \& J. M. Day (Eds.), Psychologie du développement religieux: Questions classiques et perspectives contemporaines (pp. 39-76). Geneva: Labor et Fides.

Streib, H., \& Hood, R. W. (2011). "Spirituality" as privatized experience-oriented religion: Empirical and conceptual perspectives. Implicit Religion, 14, 433-453. https://doi.org/10.1558/ imre.v14i4.433.

Streib, H., \& Hood, R. W. (Eds.). (2016a). Semantics and psychology of spirituality. A crosscultural analysis. Cham, Heidelberg, New York, Dordrecht, London: Springer International Publishing Switzerland.

Streib, H., \& Hood, R. W. (2016b). Understanding "spirituality" - conceptual considerations. In H. Streib \& R. W. Hood (Eds.), Semantics and psychology of "spirituality". A cross-cultural analysis (pp. 3-17). Cham, Heidelberg, New York, Dordrecht, London: Springer International Publishing Switzerland.

Streib, H., \& Keller, B. (2018). Manual for religious styles research (fourth, revised edition of the manual for faith development research). Bielefeld: Research Center for Biographical Studies in Contemporary Religion.

Streib, H., Hood, R. W., Keller, B., Csöff, R.-M., \& Silver, C. (2009). Deconversion. Qualitative and quantitative results from cross-cultural research in Germany and the United States of America. Göttingen: Vandenhoeck \& Ruprecht.

Streib, H., Hood, R. W., \& Klein, C. (2010). The religious schema scale: Construction and initial validation of a quantitative measure for religious styles. The International Journal for the Psychology of Religion, 20, 151-172. https://doi.org/10.1080/10508619.2010.481223.

Streib, H., Wollert, M. H., \& Keller, B. (2016). The faith development interview: Methodological considerations. In H. Streib \& R. W. Hood (Eds.), Semantics and psychology of "spirituality". A cross-cultural analysis (pp. 239-249). Cham, Heidelberg, New York, Dordrecht, London: Springer International Publishing Switzerland.

Tillich, P. (1957). Dynamics of faith. New York: Harper\&Row.

Waldenfels, B. (2011). Phenomenology of the alien: Basic concepts [Grundmotive einer Phänomenologie des Fremden, Frankfurt/M.: Suhrkamp, 2006, trans. by A. Kozin and T. Stähler]. Evanston: Northwestern University Press. 